\title{
Research on Influencing Factors of Corporate Tax Compliance Behavior: a Perspective of Corporate Governance
}

\author{
Hong-Bing YUAN ${ }^{1, a,{ }^{*}}$ \\ ${ }^{1}$ State Administration of Taxation of Futian District, Shenzhen, China \\ ayuanhb@szgs.gov.cn \\ ${ }^{*}$ Corresponding author
}

Keywords: Tax compliance, Reaction of investors, Corporate governance

\begin{abstract}
Earnings management is an important research direction for corporate finance, while tax is an important means for earnings management. Therefore, corporate tax compliance behavior plays a vital role on research of the corporate finance. This paper, based on the undersheltering puzzle, analysis of the impact of corporate tax compliance behavior. From the reaction of investors, the level of corporate governance, tax policy and other aspects discussed the manner and extent of the impact of corporate tax compliance role.
\end{abstract}

\section{Introduction}

The research on corporate tax compliance behavior has always been the important content of research on finance and accounting, and also the important characteristics of modern economic development. With the economic globalization, all countries in the world have provided wide space for the selection of corporate tax compliance behavior from the height difference on tax categories, tax rate, tax preference, etc. On this basis, the academic circles conduct focus on the individual behavior in corporate tax compliance, and regard the tax behavior entity as a rational decision-making entity, with the purpose of maximizing self-interest through all possible tax planning and selection of corporate tax compliance behavior. Under such research framework, research on surplus management, etc. are further deepened. However, in 2002, professor Weisbach, who is from Law School of University of Chicago found that the corporate compliance level of American enterprises was not so low as imagined. Even if the tax compliance cost was very low and safe, most enterprises did not choose this. Weisbach further verified this surprising discovery by actual data, and called it the undersheltering puzzle. In the presence of strong evidence, the original research cannot explain this phenomenon.

\section{Theoretical Explanation on Influencing Factors of Corporate Tax Compliance Behavior}

The undersheltering puzzle proposes severe challenge to the original research on corporate tax compliance, and the solution apparently requires the interdisciplinary view. The original research on tax compliance neglects the difference between individual and enterprise on entity, and regards them as the single tax compliance decision making and behavior implementation entity. However, as important modern economic organization, the enterprise is mainly featured in the separation of ownership and management right, especially the modern company. Therefore, if the entity of corporate tax compliance decision-making and behavior implementation cannot be clearly defined, it will be hard to deep analyze the cause and behavior characteristics of tax compliance. As a result, some scholars begin to try to introduce the variable of company governance into the research on tax compliance behavior, and separate corporate tax compliance decision-making entity from the corporate tax compliance implementation entity. When the corporate ownership is separated from management right, the corporate tax compliance decision will be made by shareholder, while the tax compliance behavior will be implemented by the company executives. Only the controlling shareholder can participate in the tax compliance decision-making and tax compliance 
implementation at the same time. Therefore, the separation of decision-making entity and implementation entity finally leads to the agency problem

For example, Tyco International is a leading supplier of global security product and service, fire protection and monitoring product and service, fluid control product. Without a controlling shareholder, the corporate tax compliance activity has agency problem and finally impairs the interests of shareholder. The data shows that since 1997, Tyco has conducted a series of tax avoidance activities, and reduced the mean tax rate of overseas earnings from $50.5 \%$ at the end of 1996 to $14.3 \%$ in 2001 through inter-enterprise loan network and tax haven subsidiary network. The activities were followed by a large number of criminal records that CEO and CFO transferred and emptied enterprise assets. These behaviors started at the end of 1997 and were rapidly expanded after 1999, till the demission of relevant personnel in 2002. It shows that although lower tax compliance level can increase corporate value, the implementation of tax avoidance strategy provides convenience for the management personnel to empty company assets. In this circumstance, the shareholders may not expect to reduce corporate tax compliance extent, and it also shows that the earnings from the tax avoidance are only a tiny part in all firm values concerned by the shareholder. Therefore, after the company governance framework is introduced and the agency relationship of modern enterprise is considered, the undersheltering puzzle can be rationally and effectively explained.

\section{Corporate Tax Compliance Extent, Reaction of Investors and Tax Policy}

The research on the influencing factors of corporate tax compliance includes corporate governance variable to the research on corporate tax compliance behavior, and provides wide view to understand the mode of corporate tax compliance. Moreover, the scholars' research on how the change of corporate governance environment affects the corporate tax compliance behavior, the reaction of capital market on the corporate tax compliance extent, and how corporate governance affects the policy and collection of tax authority.

\section{Corporate Tax Compliance Extent and Reaction of Investors}

If the tax authority finds and issues the news of low corporate tax compliance, what will be the reaction of corporate investors, what influence will it bring to the firm value? It seems easy to answer under original research framework, the low corporate tax compliance behavior will transfer fortune from the government to the investors, and the capital market investors should show positive reaction. However, the research in U.S. verifies that the relationship is not as simple as imagined. In fact, the reaction of capital market investors is closely related to the corporate governance level.

When the corporate tax compliance is low, the effect can be positive and negative. For positive effect, the enterprise reduces expenditure and creates fortune for the shareholder, for negative effect, the investors are worried about the expediency of the executives caused by corporate tax behavior. Finally, the positive effect and the negative effect comprehensively decide the direction and extent of the reaction of investors to the corporate tax compliance behavior. Corporate governance is the key factor that affects the extent of positive effect and negative effect. When the corporate governance level is low, the agency problem is not well solved, the executives' ability of expediency is strong, and the low corporate tax compliance behavior will lead to the reduction of average stock price. First, the punishment related to tax compliance leads to the reduction of firm value, second, the investors may consider that the possibility for the expedience of management personnel is high. When the corporate governance level is high, the possibility for the management personnel to seek for personal gain is very low, low corporate tax compliance extent creates value for the shareholder and receives the positive reaction of the investors. Hanlon and Slemrod (2006), Desai and Dharmapala (2006) and Wilson (2007) have verified this phenomenon through using the panel data of American companies. Therefore the reaction of investors to the corporate tax compliance activity depends on the corporate governance level. In the enterprises with improved corporate governance, low corporate tax compliance creates value for the enterprises, while in the 
enterprises with unimproved corporate governance, low corporate tax compliance may impair the interests of the investors, and receive negative evaluation from the capital market.

\section{Corporate Governance Level and Tax Policy}

The research on the undersheltering puzzle does not only define the corporate compliance decision-making entity and tax compliance implementation entity, but also extend the participation entity of the whole tax compliance system. In the traditional research framework, there are only two entities as enterprise and tax authority, after corporate governance is introduced, the participation entities are increased to corporate insiders, external investors and tax authority. In this system, corporate governance also plays an important role in the corporate tax system.

First, from the degree of business income tax rate, the formulation of tax rate cannot be separated from the consideration of local corporate governance level. The research in U.S. finds that when the corporate governance system is not improved, the increase of tax rate will reduce tax revenue, the increase of tax rate can increase tax revenue only when the corporate governance level is high. At the same time, the increase of business income tax rate will deteriorate the corporate governance level and increase the transfer behavior of management personnel.

Second, the tax enforcement effort is also closely related to the corporate governance level. For example, in Russia, the corporate governance level was low, and the expedience behavior of management personnel was rampant. In 2000, President Putin conducted a series of tax inspection on the oil enterprises in Russia, and strengthened tax enforcement efforts. These actions do not only increase the national revenue, but also are well received by the capital market. In the economic environment with poor corporate governance, the reinforcement of tax enforcement effort can reduce the expedience behavior of management personnel and create value for the shareholder. Therefore, as for the set business income tax rate, the reinforcement of tax enforcement effort improves the firm value and corporate governance level. At this moment, minority shareholder is in the hitchhiking position, and business income tax can be regarded as the expense paid by minority shareholders for the specific service of tax department.

\section{Conclusions and Prospects}

The following conclusions and prospects can be obtained from the current international research on corporate tax compliance:

Firstly, after Weisbach proposed the undersheltering puzzle, foreign research on corporate tax compliance had been divided into two directions: one is represented by Graham and Tucker, who consider that the low tax compliance only reduces tax burden and improves value of the enterprise under the traditional framework, with agency problem. Another is represented by Dysai, Dyck and Wilson, etc., who consider the agency problem as the inherent enterprise problem with great influence on the corporate tax compliance, and the tax compliance, tax compliance mode and reaction of investors can be explained only after being included in corporate governance.

Secondly, the introduced corporate governance variable expands idea for the research on corporate tax compliance. However, compared to other countries, American enterprises have high governance level and low ownership concentration. At present, most research achievements are based on the ownership characteristics of American companies. To most countries in the world, the ownership concentration, agency relationship characteristics and corporate income collection and administration system are greatly varied from U.S. There is no systematical research on the influence of these differences between the corporate tax compliance behavior and the reaction of capital market to these behaviors. In China, the legal background and corporate right of control are greatly different from the U.S., therefore, under the framework of such background and agency problem, the analysis of the motive and behavior of Chinese corporate tax compliance has important meaning to in-depth understanding of corporate finance.

Finally, the research on the influencing factors of corporate tax compliance introduces corporate governance framework and agency relationship into the research on corporate tax compliance, broadens view for the formulation and execution of tax policy, and also provides new idea for the 
business income tax collection and administration work of tax authority. On one hand, when the business income tax rate is formulated, the governance structure and level of Chinese enterprises shall be fully researched to give consideration to both the increase of tax revenue and improvement of corporate governance level. On the other hand, the reinforcement of business income tax enforcement work has important value to the corporate finance. When the corporate governance system is not improved, the enhanced tax enforcement effort will have important meaning to national, corporate investors and tax authority. It does not only increase national tax revenue, but also create fortune for the shareholder through the supervision over management personnel, improve corporate governance system, and provide certain guarantee to the healthy development of Chinese enterprises.

\section{References}

[1] La Porta, Rafael, Florencio Lopez-de-Silanes, Andrei Shleifer and Robert W. Vishny. Legal determinants of external finance[J].The Journal of Finance 1997,52(3):1131-1150.

[2] La Porta, Rafael, Florencio Lopez-de-Silanes, Andrei Shleifer and Robert W. Vishny. Law and finance[J]. Journal of Political Economy, 1998,Vol. 106:1113-1155.

[3] Zingales, Luigi. The value of the voting right: a study of the Milan stock exchange[J].The Reviews of Financial Studies, 1994,7,125-148.

[4] La Porta, Rafael, Florencio Lopez-de-Silanes, Andrei Shleifer and Robert W. Vishny. Investor protection and corporate valuation[J].The Journal of Finance, 2002, 57:1147-1170.

[5] Shen Yifeng, Shen Hongtao. Company Financial Theory Mainstream [M]. Dalian: Dongbei University of Finance Press, 2004.

[6] Jensen, M. The modern industrial revolution, exit, and the failure of internal control system[J].Journal of Finance, 1993,58:831-880.

[7] La Porta, Rafael, Florencio Lopez-de-Silanes, Andrei Shleifer and Robert W. Vishny. The quality of government[J]. Journal of Law, Economics and Organization, 1999,15:222-279.

[8] La Porta, Rafael, Florencio Lopez-de-Silanes, Andrei Shleifer and Robert W. Vishny. Investor protection and corporate governance[J].Journal of Financial Economics, 2000,Vol. 58(1-2).

[9] Coffee J. The rise of dispersed ownership: the role of law in the separation of ownership and control[ R ]. Columbia Law School Working Paper, 2001.

[10] Cheffins B. Does Law Matters? The separation of ownership and control in the United Kingdom[R ]. SSRN Working Paper, 2000.

[11] Zheng Zhigang. Exlex Corporate Governance Role -A Literature Review [J]. Management World, September 2007: 136-147

[12] David A. Weisbach. Ten Truths about Tax Shelters[W]. The University of Chicago Law School Working Paper, 2002.8.

[13] Mihir Desai,Alexander Dyck,Luigi Zingales. Theft and taxes [J]. Journal of Financial Economics, 2007, 84: 591-623.

[14] Mihir Desai,Dhammika Dharmapala. Corporate tax avoidance and firm value [J].Harvard University and NBER Working paper,2006.

[15] Mihir Desai,Dhammika Dharmapala. Corporate tax avoidance and high-powered incentives[J]. Journal of Financial Economics,2006, 79: 145-179.

[16] Mihir Desai,Alexander Dyck,Luigi Zingales. The Protecting Hand: Taxation and Corporate Governance [J]. Harvard University and NBER Working paper, 2003. 